\title{
Interferon- $\gamma$ Contributes to HLA-B27-associated Unfolded Protein Response in Spondyloarthropathies
}

\author{
YUAN FENG, JIN DING, CHUN MEI FAN, and PING ZHU
}

\begin{abstract}
Objective. HLA-B27 positivity strongly influences the susceptibility to and phenotype of spondyloarthropathies $(\mathrm{SpA})$. This study was designed to screen factors that activate the promoter of HLA-B27 in U937 cells, and to assess whether these promoter-activating factors induce the unfolded protein response (UPR) in HLA-B27-expressing cells.

Methods. Cytometric Bead Array, flow cytometry, and real-time polymerase chain reaction were used to detect the expression of cytokines and UPR-associated proteins in peripheral blood and synovial fluid of patients with SpA. The HLA-B27 promotor transfectant was incubated separately with cytokines and Toll-like receptor ligands. After interferon- $\gamma$ (IFN- $\gamma$ ) stimulation, expressions of GRP78, CHOP, and XBP-1 were tested in HLA-B27-expressing U937 cells and peripheral blood mononuclear cell (PBMC) of patients with ankylosing spondylitis (AS). (Clinical trial registration no. ChiCTR-OCC-11001565)

Results. Expressions of GRP78, CHOP, and XBP-1 in monocytes/macrophages of SpA peripheral blood and synovial fluid were higher than those in healthy controls and patients with osteoarthritis (OA) $(\mathrm{p}<0.05)$. Tumor necrosis factor- $\alpha($ TNF- $\alpha)$ and IFN- $\alpha$, IFN- $\beta$, and IFN- $\gamma$ were found to have activated the HLA-B27 promoter in the U937 cell line $(\mathrm{p}<0.05)$. Following stimulation with IFN- $\gamma$, the expressions of GRP78, CHOP and XBP-1 in HLA-B27-transfected U937 cells and PBMC of HLA-B27-positive AS patients were more intense than those in A2-U937 cells, HLA-B27-negative AS patients, or healthy controls $(\mathrm{p}<0.05)$.

Conclusion. Expressions of GRP78, CHOP, and XBP-1 were higher in monocytes/macrophages of patients with SpA than those in both OA patients and healthy controls, suggesting that UPR may participate in the pathogenesis of SpA. TNF- $\alpha$ and IFN- $\alpha$, IFN- $\beta$, and IFN- $\gamma$ significantly activated HLA-B27 promoter in the U937 cell line, and IFN- $\gamma$, the strongest activating factor, may induce the UPR in HLA-B27-expressing cells. (First Release Jan 15 2012; J Rheumatol 2012;39:574-82; doi:10.3899/ jrheum.101257)
\end{abstract}

Key Indexing Terms:

HLA-B27 SPONDYLOARTHROPATHY

INTERFERON- $\gamma$

TUMOR NECROSIS FACTOR- $\alpha$ UNFOLDED PROTEIN RESPONSE

Spondyloarthropathies $(\mathrm{SpA})$ are a cluster of interrelated and overlapping chronic inflammatory rheumatic diseases that primarily include ankylosing spondylitis (AS), reactive arthritis (ReA), psoriatic arthritis (PsA), and inflammatory bowel disease arthritis. SpA commonly cause inflammation of the spine, eye, bowel, genital tract, or skin. SpA present striking familial aggregations and are typically associated with HLA genes, particularly HLA-B2 $7^{1,2}$. But it remains unclear how HLA-B27 contributes to arthritis. Different hypotheses have been formulated to explain this association:

From the Department of Clinical Immunology, State Key Discipline of Cell Biology, Xijing Hospital, Fourth Military Medical University, Xi'an, Shaanxi Province, China.

Y. Feng, PhD; J. Ding, PhD; C.M. Fan, BA; P. Zhu, MD, Professor, Department of Clinical Immunology, State Key Discipline of Cell Biology, Xijing Hospital, Fourth Military Medical University.

Dr. Feng and Dr. Ding contributed equally to this work.

Address correspondence to Dr. P. Zhu, Department of Clinical Immunology, State Key Discipline of Cell Biology, Xijing Hospital, Fourth Military Medical University, 15 Changlexi Road, Xi'an, Shaanxi Province, China.E-mail: zhuping@fmmu.edu.cn

Accepted for publication October 17, 2011. among them, the presentation of exogenous or self-peptides to HLA-B27+CD8+ T cells, the antigen presentation by HLA-B27 free heavy-chain homodimers, and HLA-B27 misfolding and the endoplasmic reticulum unfolded protein response (ER UPR $)^{3}$. In addition, other mechanisms such as interaction of cell-surface dimers with killer cell Ig-like receptors (KIR) have been shown by Bowness, et $a l^{4}$. These hypotheses are all based on the activities of HLA-B27 protein. It is believed that in addition to certain other genes and/or environmental factors, the degree of expression of the HLA-B27 gene is also responsible for the susceptibility to SpA. Taurog, et al have shown that in HLA-B27*05 transgenic rats, the degree of susceptibility of various lines to the development of an SpA-like spectrum of lesions correlates with the level of HLA-B27 transgene expression at the mRNA and protein levels ${ }^{5}$. Cauli, et al reported that the expression of HLA-B27 molecule on the surface of peripheral blood mononuclear cells (PBMC) was higher in patients with AS than in HLA-B27-positive healthy volunteers ${ }^{6}$. However, very little research has been conducted to investigate HLA-B27 gene regulation.

Personal non-commercial use only. The Journal of Rheumatology Copyright $@$ $\subset$ 2012. All rights reserved. 
The findings that misfolded HLA-B $27^{7}$ can form aberrant disulfide-linked homodimers ${ }^{8}$ have brought forth some hypotheses concerning the role of HLA-B27 in the pathogenesis of SpA. One hypothesis is that HLA-B27 causes arthritis by inducing an "endoplasmic reticulum unfolded protein response" 9 . In an HLA-B27 transgenic rat model, it was proven that the UPR is activated in macrophages derived from the bone marrow of HLA-B27 transgenic rats with inflammatory diseases. The degree of HLA-B27 upregulation correlates with the magnitude of UPR activation, as shown using cytokines that upregulate HLA class I expression ${ }^{10,11} . \mathrm{Gu}$, et al reported overexpression of a UPR target gene (BiP) in adherent synovial fluid (SF) mononuclear cells from active joints of HLA-B27-positive patients with $\mathrm{SpA}$, in comparison with $\mathrm{BiP}$ expression in patients with rheumatoid arthritis ${ }^{12}$. These findings suggest that under certain circumstances, such as stimulation of some cytokines in SpA monocytes/macrophages, increased expression of HLA-B27 may result in HLA-B27 misfolding in the ER, which may in turn induce activation of the UPR.

We investigated the expression of cytokines and UPR-related molecules in monocytes/macrophages of peripheral blood (PB) and SF of patients with active SpA. We wished to identify the factors that might be responsible for the transcription of HLA-B27 in human monocytic cells, and to assess whether any differences in UPR can be detected after incubation with promoter-activating factors in HLA-B27 whole-gene transfectants.

\section{MATERIALS AND METHODS}

Patients. Specimens of PB were obtained from 20 patients with active SpA (16 AS, 4 ReA), 10 patients with OA, and 10 healthy volunteer blood donors. Specimens of synovial fluid (SF) were taken at surgeries from 12 patients with SpA (10 AS, 2 ReA) and 10 with OA. Demographic characteristics of patients and controls are summarized in Table 1. Patients and controls were matched for number, age, sex, and disease duration.

Patients were considered to have $\mathrm{SpA}$ and $\mathrm{OA}$ if they fulfilled the European Spondylarthropathy Study Group and American College of Rheumatology clinical criteria. Patients who received biological and systemic steroid therapy were excluded, and patients treated with disease-modifying antirheumatic drugs (DMARD) were included. The Bath Ankylosing Spondylitis Disease Activity Index (BASDAI) and Bath Ankylosing Spondylitis Function Index (BASFI) of all patients with SpA were $>4.0$. Ethics approval was granted for this study and all subjects pro-

Table 1. Demographic indicators and disease characteristics of patients with $\mathrm{SpA}$ and healthy controls.

\begin{tabular}{lccc}
\hline Characteristics & SpA & OA & Controls \\
\hline No. & 20 & 10 & 10 \\
Female/male & $4 / 16$ & $6 / 4$ & $2 / 8$ \\
Median age, yrs & 29 & 62 & 26 \\
$\quad$ Range & $21-37$ & $58-66$ & $23-30$ \\
Median disease duration, yrs & 4.28 & 8.25 & \\
$\quad$ Range & $2-7$ & $5-12.5$ & \\
No. HLA-B27-positive & 15 & 1 & 2 \\
\hline
\end{tabular}

vided their informed consent. The clinical trial registration number is ChiCTR-OCC-11001565.

Blood and SF specimens. All blood and SF samples were collected into collection tubes containing $0.2 \mathrm{ml}$ sodium heparin. Mononuclear cells were obtained from PB and SF by Ficoll density gradient centrifugation method. Then, mononuclear cells were washed and resuspended in phosphate buffered saline ( $1 \%$ bovine serum albumin) at a concentration of $2 \times 10^{9} / 1$. Plasma was obtained after centrifugation and stored at $-80^{\circ} \mathrm{C}$.

Plasmids. The pmaxFP-Yellow-PRL/B27-pro vector containing 432-bp promoter region of HLA-B2705 was kindly provided by D. Yu and colleagues, University of California Los Angeles (UCLA). The plasmid-containing genomic HLA-A2 was a gift from M. Shi, Fourth Military Medical University. The resulting recombinant plasmids were sequenced to ensure that only the intended alteration had been made. Yellow fluorescent proteins were used as reporter genes for pmaxFP-Yellow-PRL.

Cell culture and transfectants. U937 cell line was purchased from the Cell Bank of the Chinese Academy of Sciences (Shanghai, China). To create stable cell lines expressing B27-pmaxFP-Yellow-PRL and HLA-A2, cells were transfected with expression vectors using Lipofectamine 2000 (Invitrogen, Carlsbad, CA, USA) and selected for with $0.8 \mathrm{mg} / \mathrm{ml} \mathrm{G} 418$ (Invitrogen). Expression of HLA-A2 by transfectants was detected using the HLA-A2-specific antibody, MA2.1 (US Biological, Salem, MA, USA). Clonal and bulk cultures expressing high amounts of YFP and HLA-A2 were selected by flow cytometry and were used for experiments.

The U937 cells transfected with human HLA-B2704 genomic DNA sequence were provided by D. Yu and colleagues, UCLA. Expression of HLA-B27 by transfectants was detected using the HLA-B27-specific antibody, ME1 (gift from Prof. D. Yu).

These transfectants were designated the "promoter-B27-U937," the "A2-U937," and the "B27-U937." Transfected cells were cultured in RPMI-1640 medium (Invitrogen) with $10 \%$ fetal calf serum at $37^{\circ} \mathrm{C}$ in a humidified atmosphere containing $5 \% \mathrm{CO}_{2}$. Media for the transfectants were supplemented with $0.2 \mathrm{mg} / \mathrm{ml} \mathrm{G} 418$.

$100 \mathrm{ng} / \mathrm{ml}$ interferon- $\gamma$ (IFN- $\gamma$; Sigma, St. Louis, MO, USA) and 20 $\mathrm{ng} / \mathrm{ml}$ tumor necrosis factor- $\alpha$ (TNF- $\alpha$; eBioscience, San Diego, CA, USA) were used as stimulators to activate transfected U937 and PBMC of AS patients for $24 \mathrm{~h}$ and $8 \mathrm{~h}$, respectively. The concentration and incubation time were optimized by pre-experiments.

Cytokine assay. Cytokine profiles were investigated using separated serum samples. Serum was separated by centrifugation and stored in aliquots at $-80^{\circ} \mathrm{C}$ until analysis. Serum cytokine levels were investigated using Cytometric Bead Arrays (BD Biosciences, San Jose, CA, USA) and the levels of inflammatory cytokines [TNF- $\alpha$, interleukin $1 \beta$ (IL-1B), IL-6, IL-8, IL-10, and IL-12p70] were measured. Briefly, $50 \mu 1$ of samples or known concentrations of standard samples $(0-5000 \mathrm{pg} / \mathrm{ml})$ were added to a mixture of $50 \mu 1$ each of capture-antibody bead reagent and detector antibody phycoerythrin $(\mathrm{PE})$ reagent. The mixture was subsequently incubated $3 \mathrm{~h}$ at room temperature away from light and washed to remove unbound detector antibody PE reagent. Data were acquired by flow cytometry (FACS Calibur, BD Biosciences) and analyzed using cytometric bead array software 1.1 (BD Biosciences).

Flow cytometry analysis. Antibodies used were goat polyclonal anti-GRP78 antibody (Santa Cruz Biotechnology, Santa Cruz, CA, USA), rabbit polyclonal anti-CHOP (c/enhancer binding protein homologous protein 10) antibody (Santa Cruz Biotechnology), IgG2a isotype control (Serotec, Kidlington, UK), IgG1 isotype control (Serotec), FITC rabbit anti-goat IgG (Vector Laboratories, Burlingame, CA, USA), FITC goat anti-rabbit IgG (Vector), PerCP-conjugated anti-CD3 monoclonal antibodies (BD Biosciences), and PerCP-conjugated anti-CD14 monoclonal antibodies (BD Biosciences). Prior to staining, cells were blocked in $1 \%$ normal human serum to prevent nonspecific Fc receptor-binding. The separated mononuclear cells of PB or SF were permeabilized in suspension with FACS fixing/permeabilizing solution (BD Biosciences), and then labeled in turn with goat polyclonal anti-GRP78 antibody or anti-CHOP antibody, the

Personal non-commercial use only. The Journal of Rheumatology Copyright ( 2012. All rights reserved. 
second antibody (rabbit anti-goat-FITC or goat anti-rabbit-FITC), and then PerCP-CD3-MAb or PerCP-CD14-MAb. Suitable negative isotype controls were used to block the background fluorescence. By running an appropriate negative isotype control and overlaying its image on the histogram, the positive dataset is identified as the peak completely separate from the negative isotype control. CD3+ and CD14+ cells were gated and data were processed using the CellQuest software (BD Biosciences). The percentage of each positive population and mean fluorescence intensity was determined using histogram statistics.

The U937 cells transfected with yellow fluorescent protein reporter gene controlled by HLA-B27 promoter were incubated separately with 25 different cytokines [IL-1 $\alpha$, IL-1ß, IL-2, IL-4, IL-5, IL-6, IL-7, IL-8, IL-12-p70, IL-13, IL-15, IL-17, IL-18, TNF- $\alpha$, macrophage colony-stimulating factor, granulocyte-macrophage colony-stimulating factor, IP-10, monocyte chemoattractant protein-1 (MIP-1), RANTES, MIP-1 $\alpha$, IFN- $\alpha$, IFN- $\beta$, IFN- $\gamma$, transforming growth factor- $\beta 1$, and OSM] and 12 different Toll-like receptor (TLR) ligands (MDP, PGN, Zyn, PIC, LPS, Flag, FSL, Lox, ssRNA, EcDNA, Pams, and Decap KP) for an additional 24, 48, and $72 \mathrm{~h}$. Concentrations of cytokines and TLR ligands are shown in Table 2. The cells were analyzed with flow cytometry (FACS Calibur, BD Biosciences). The excitation wavelength was $488 \mathrm{~nm}$ and emission was

Table 2. Concentrations of cytokines and Toll-like receptor ligands.

\begin{tabular}{lc}
\hline Molecule & Working Concentration \\
\hline IL-1 $\alpha$ & $10 \mathrm{ng} / \mathrm{ml}$ \\
IL-1ß & $10 \mathrm{ng} / \mathrm{ml}$ \\
IL-2 & $2 \mathrm{ng} / \mathrm{ml}$ \\
IL-4 & $50 \mathrm{ng} / \mathrm{ml}$ \\
IL-5 & $60 \mathrm{ng} / \mathrm{ml}$ \\
IL-6 & $200 \mathrm{ng} / \mathrm{ml}$ \\
IL-7 & $10 \mathrm{ng} / \mathrm{ml}$ \\
IL-8 & $100 \mathrm{ng} / \mathrm{ml}$ \\
IL-10 & $100 \mathrm{ng} / \mathrm{ml}$ \\
IL-12p70 & $40 \mathrm{ng} / \mathrm{ml}$ \\
IL-13 & $20 \mathrm{ng} / \mathrm{ml}$ \\
IL-15 & $50 \mathrm{ng} / \mathrm{ml}$ \\
IL-17 & $50 \mathrm{ng} / \mathrm{ml}$ \\
IL-18 & $100 \mathrm{ng} / \mathrm{ml}$ \\
TNF- $\alpha$ & $20 \mathrm{ng} / \mathrm{ml}$ \\
M-CSF & $10 \mathrm{ng} / \mathrm{ml}$ \\
GM-CSF & $80 \mathrm{ng} / \mathrm{ml}$ \\
IP-10 & $50 \mathrm{ng} / \mathrm{ml}$ \\
MCP-1 & $20 \mathrm{ng} / \mathrm{ml}$ \\
RANTES & $10 \mathrm{ng} / \mathrm{ml}$ \\
MIP-1 $\alpha$ & $10 \mathrm{ng} / \mathrm{ml}$ \\
IFN- $\alpha$ & $1000 \mathrm{U} / \mathrm{ml}$ \\
IFN- $\beta$ & $1000 \mathrm{U} / \mathrm{ml}$ \\
IFN- $\gamma$ & $50 \mathrm{ng} / \mathrm{ml}$ \\
TGF- $\beta$ & $10 \mathrm{ng} / \mathrm{ml}$ \\
OSM & $100 \mathrm{ng} / \mathrm{ml}$ \\
PMA & $10 \mathrm{E}-7 \mathrm{M}$ \\
MDP & $20 \mu \mathrm{g} / \mathrm{ml}$ \\
PGN & $10 \mu \mathrm{g} / \mathrm{ml}$ \\
Zyn & $10 \mu \mathrm{g} / \mathrm{ml}$ \\
PIC & $25 \mu \mathrm{g} / \mathrm{ml}$ \\
LPS & $1 \mu \mathrm{g} / \mathrm{ml}$ \\
Flag & $0.1 \mu \mathrm{g} / \mathrm{ml}$ \\
FSL & $1 \mu \mathrm{g} / \mathrm{ml}$ \\
LOX & $500 \mu \mathrm{M}$ \\
ssRNA & $1 \mu \mathrm{g} / \mathrm{ml}$ \\
EcDNA & $5 \mu \mathrm{g} / \mathrm{ml}$ \\
Pams & $1 \mu \mathrm{g} / \mathrm{ml}$ \\
\hline & \\
& \\
&
\end{tabular}

detected using a 530-nm bandpass filter. Measurements were done on triplicate samples and repeated 3 times.

Semiquantitative and quantitative polymerase chain reaction (PCR). RNA was extracted from patients' PBMC using Trizol reagent. Real-time PCR was performed using a CFD3120 MiniOpticon Detector (Bio-Rad, Hercules, CA, USA) with double-stranded DNA-specific fluorophore SybrGreen I (Molecular Probes, Eugene, OR, USA). Analysis of each test gene was performed in triplicate and normalized to the corresponding 18S-rRNA values. The relative expression of XBP-1 (X-box binding protein 1) to the XBP-1 splice variant was determined by electrophoresis of XBP-1 PCR products on 1.5\% agarose gels. The proportions of unspliced (480-bp) to spliced (454-bp) products were determined using BandScan image analysis software.

Western blots. Cells were lysed with $2 \times$ sodium dodecyl sulfate reducing buffer, and polyacrylamide gel electrophoresis was performed on $8 \%-16 \%$ Tris-glycine gradient gels (Invitrogen). Proteins were transferred onto polyvinylidene fluoride membranes and blocked with $20 \mathrm{mmol} / \mathrm{l}$ Tris, 140 $\mathrm{mmol} / 1 \mathrm{NaCl}, 0.1 \%$ Tween $20,10 \%$ powdered dry milk protein [Tris $(20$ mmol/l)(TBS-Tween)/milk]. Probes were blotted with anti-GRP78 goat polyclonal antibody or rabbit polyclonal anti-CHOP antibody (Santa Cruz Biotechnology) for $1 \mathrm{~h}$ at room temperature. Blots were washed 3 times with TBS-Tween and incubated with horseradish peroxidase-conjugated bovine anti-goat or goat anti-rabbit IgG (Santa Cruz Biotechnology) for 1 $\mathrm{h}$ at room temperature. Blots were washed 3 times with TBS-Tween and developed with ECL reagent (Sigma). The experiments were repeated 2 to 4 times.

Viability colorimetric assays. Cell viability was assessed by CellTiter $96^{\circledR}$ AQueous One solution cell proliferation assay (Promega, Madison, WI, USA). In all experiments, the viability was near $90 \%$ and did not vary with the reagents added.

Statistics. Assessments of statistical results were done by paired t test and ANOVA (Dunnett's and LSD test), and p values $<0.05$ were considered significant.

\section{RESULTS}

Expression of UPR-associated proteins in CD14+ cells of $P B$ and $S F$ of $S p A$. Mononuclear cells of PB or SF were permeablized and stained with anti-GRP78 and anti-CHOP antibody, respectively. Antibody-binding to $\mathrm{CD} 3+$ or CD14+ subpopulations was evaluated by flow cytometry. The mean fluorescence intensity of positive-staining cells in 3 groups did not have great differences (data not shown). However, as shown in Figure 1A, the percentages of GRP78- and CHOP-positive staining cells in CD14+ monocytes in $\mathrm{SF}$ and $\mathrm{PB}$ of SpA were higher than those in OA and healthy controls ( $p<0.05$, LSD test). Real-time PCR results showed that GRP78 and CHOP expressions of PBMC were significantly higher in SpA groups compared with controls ( $\mathrm{p}<0.05$, LSD test; Figure 1B). We analyzed the expression of total XBP-1 (Figure 1C) and an XBP-1 splice variant with a 26-nucleotide region excised by IRE1 following stimulation of UPR ${ }^{13}$. The amount of the splice variant could be expressed as a proportion of total XBP-1, as shown in Figure 1C. XBP-1 splice variant from PB of patients with SpA showed a significant increase compared with that from PB of controls.

Expression of inflammatory cytokine in SpA $P B$. Concentrations of inflammatory cytokines (TNF- $\alpha$, IL-1ß, IL-6, IL-8, IL-10, and IL-12p70) were measured by cyto-

Personal non-commercial use only. The Journal of Rheumatology Copyright @ 2012 . All rights reserved. 

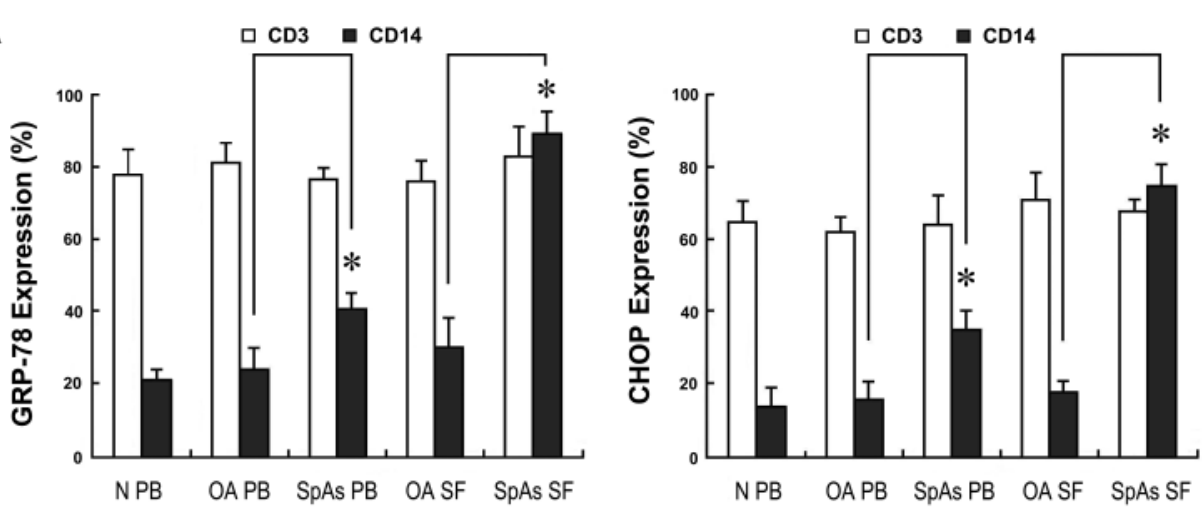

B

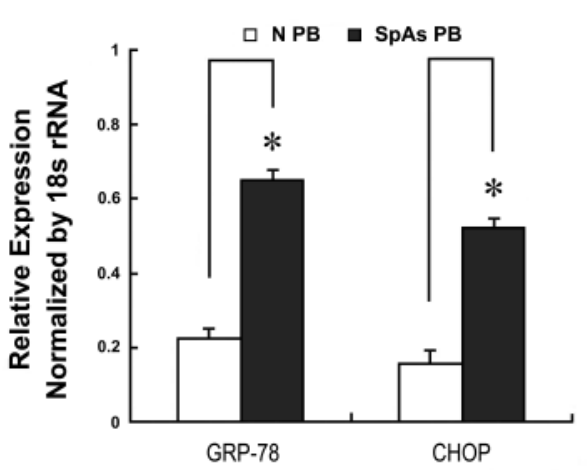

C

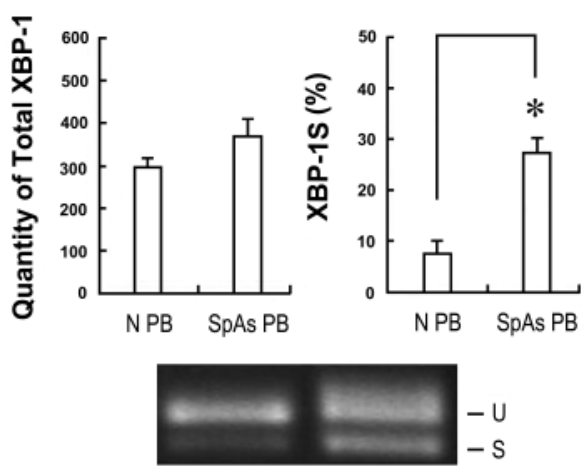

Figure 1. Expression of unfolded protein response (UPR)-associated proteins in peripheral blood (PB) or/and synovial fluid (SF) of SpA and OA patients and healthy controls. Specimens of PB were obtained from 20 patients with SpA, 10 patients with OA, and 10 healthy volunteer donors (N PB). Specimens of SF were obtained from 13 patients with SpA and 10 patients with OA. A. Expression of GRP78 and CHOP was analyzed by flow cytometry. An appropriate isotype-matched antibody was used as negative control to rule out background fluorescence. The percentage of positive cells was monitored by flow cytometric analysis after gating the $\mathrm{CD} 3+$ or CD14+ cells. B. RNA isolated from PBMC of SpA patients, OA patients, and controls was analyzed for expression of GRP78 and CHOP using quantitative PCR. C. Total XBP-1 and the XBP-1 splice variant were analyzed using semiquantitative PCR. XBP-1 spliced is expressed as a percentage of total XBP-1 unspliced. Data are presented as relative expression normalized by $18 \mathrm{~S}$ rRNA. These data were obtained from 4 independent experiments and are shown as the means \pm SD. *Significant differences $(p<0.05)$ compared to control group.

metric bead array. As shown in Figure 2, expressions of TNF- $\alpha$, IL-10, IL-6, and IL-1ß were higher in SpA PB compared with controls $(\mathrm{p}<0.05$, LSD test). However, the levels of IL-12p70 were undetectable.

Effect of cytokines and TLR ligands on HLA-B27 promoter in U937 transfectants. To investigate a possible modulatory effect of HLA-B27 on monocyte response to cytokines and TLR ligands, we utilized the monocytic cell line U937 as host cell line for transfection of HLA-B27 promoter regions. Transfectants were tested by flow cytometry after incubation with 25 different cytokines and 12 different TLR ligands for $24 \mathrm{~h}, 48 \mathrm{~h}$, and $72 \mathrm{~h}$. Only TNF- $\alpha$, IFN- $\alpha$, IFN- $\beta$, and IFN- $\gamma$ activated the HLA-B27 promoter $(\mathrm{p}<0.05$, Dunnett's test). The increased effects and the incubation times were positively correlated for $72 \mathrm{~h}$. When the peaks were compared, the most effective cytokine was IFN- $\gamma$
(Figure 3). To test the dose-response relationship for HLA-B27 promoter activity in response to these cytokines, we incubated transfectants with different concentrations of TNF- $\alpha$ and IFN- $\gamma$, and found no significant differences in this cell line. The U937 cell line is a monocyte cell line that requires differentiation with PMA to induce macrophage differentiation and expression of CD14. Accordingly, we used PMA to incubate U937 cells for $24 \mathrm{~h}$ and then added cytokines and TLR ligands to the differentiated cells. The results also showed that only TNF- $\alpha$, IFN- $\alpha$, IFN- $\beta$, and IFN- $\gamma$ significantly activated the HLA-B27 promoter, and there was no synergistic effect of PMA and cytokines (data not shown).

Expression of UPR-associated proteins in HLA-B27-expressing U937 cells. Plasmids containing HLA-B27 and HLA-A2 genomic DNA were used in this experiment to test

Personal non-commercial use only. The Journal of Rheumatology Copyright $@$ C 2012. All rights reserved. 


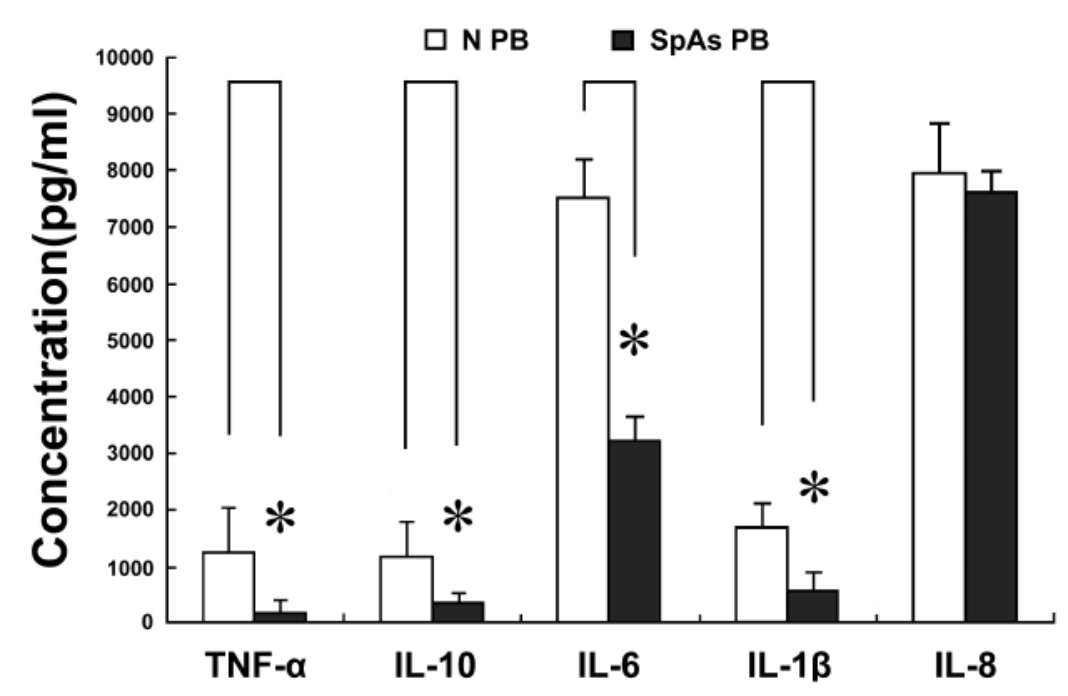

Figure 2. Expression of proinflammatory cytokines $(\mathrm{pg} / \mathrm{ml})$ in supernatants of PBMC from 20 patients with SpA and 10 healthy controls (N PB) was determined by human inflammatory cytokine CBA kit using flow cytometry. Data are presented as the average fluorescence intensity; data are means \pm SD of 3 independent experiments. *Significant differences $(\mathrm{p}<0.05)$ compared to control.

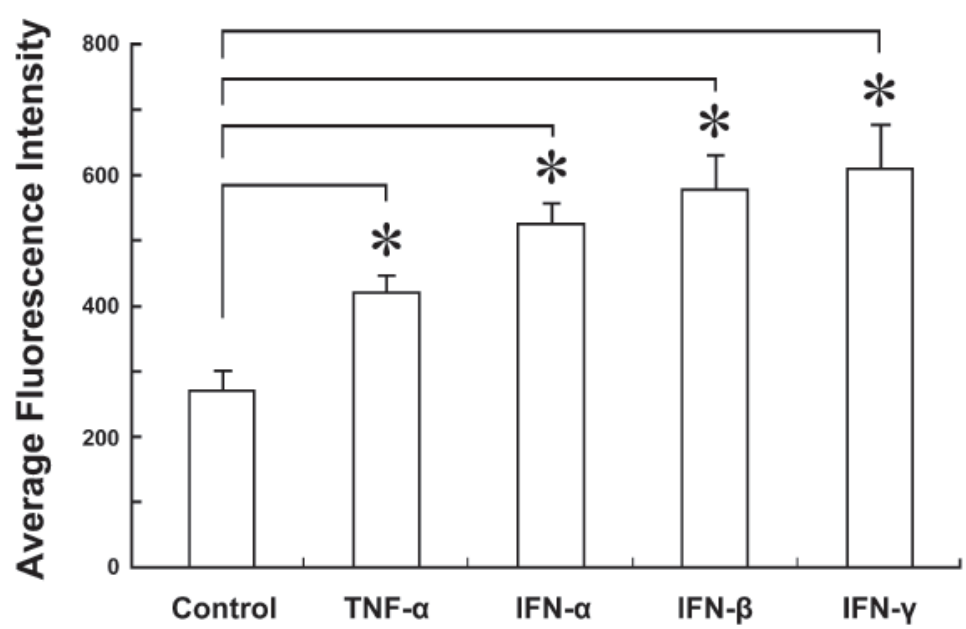

Figure 3. Evaluation of the effect of cytokines on HLA-B27 promoter activity in U937 cells. Data are presented as average fluorescence intensity analyzed by flow cytometry, representing means \pm SD of 3 independent experiments. After incubation with cytokines for 72 hours, compared to control samples, $p$ values for TNF- $\alpha$, IFN- $\alpha$, IFN- $\beta$, and IFN- $\gamma$ were $0.024,0.015,0.025$, and 0.033 , respectively. *Significant differences $(\mathrm{p}<0.05)$ compared to control group.

mRNA and protein expression of UPR-associated proteins in HLA-B27 whole-gene transfectants. To further assess the relationship between the induction of HLA-B27 and the activation of UPR, we treated cells with HLA-B27 promoter-activating factors (IFN- $\gamma$ and TNF- $\alpha$ ). Expressions of HLA-B27 in B27-U937 cells treated with IFN- $\gamma$ increased significantly ( $<<0.05$; Figure $4 \mathrm{~A}$ ). Without stimulation of cytokines, no significant differences were observed in expressions of GRP78 and CHOP between HLA-B27-positive U937 cells and HLA-A2-positive U937 cells (Figure 4B, 4C). After $24 \mathrm{~h}$ stimulation with IFN- $\gamma$ and TNF- $\alpha$, expressions of GRP78 and CHOP in B27-U937 cells were more intense than those in A2-U937 cells in the IFN- $\gamma$ group ( $\mathrm{p}<0.05$, LSD test; Figure 4B, 4C), but no significant differences were observed in the TNF- $\alpha$ group (data not shown). The quantity of total XBP-1 and relative expression

Personal non-commercial use only. The Journal of Rheumatology Copyright @ 2012. All rights reserved. 

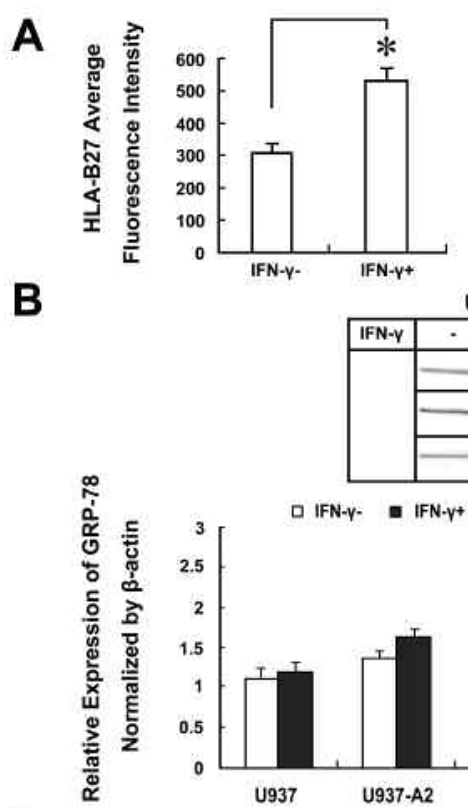

C
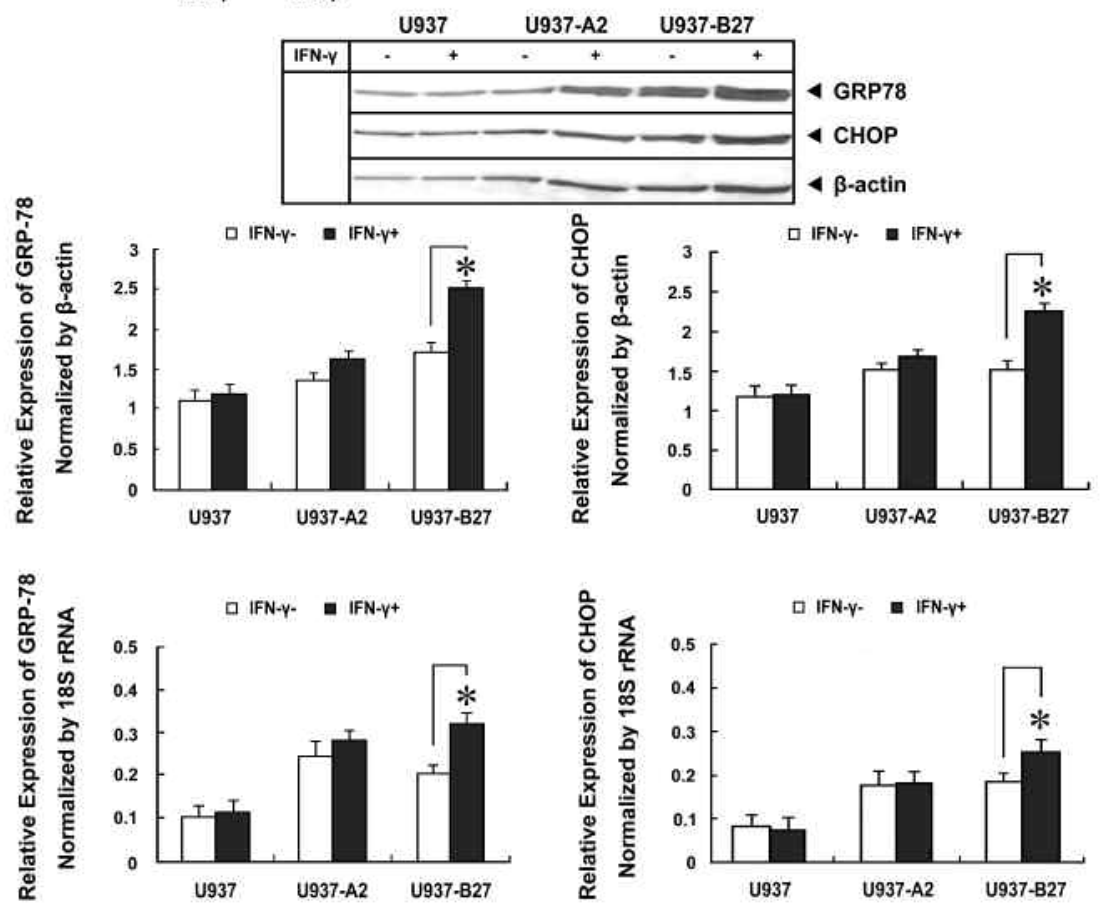

D

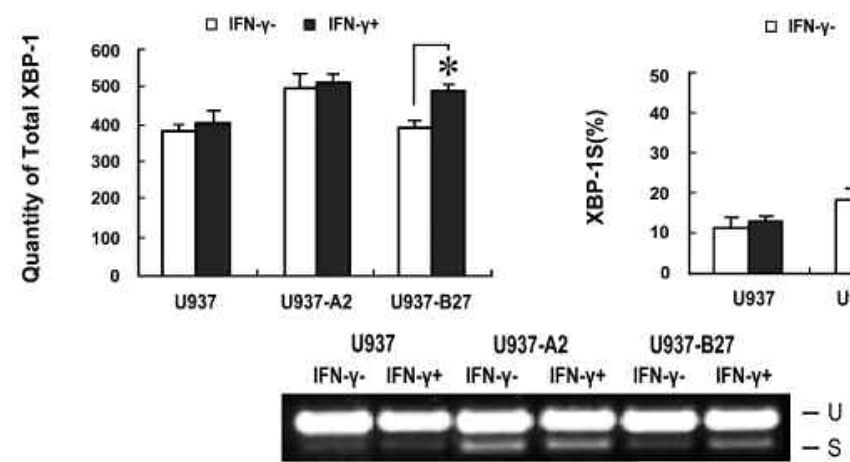

Figure 4. Expression of unfolded protein response (UPR)-associated proteins in U937 cells can be modulated by HLA-B27 after stimulation with IFN- $\gamma$. A. HLA-B27 expression of B27-U937 cells was detected by flow cytometry. B. GRP78 and CHOP protein extracts from cells were subjected to Western blot analysis with antibodies against GRP78, CHOP and B-actin. The intensity of the protein bands was quantified by densitometry and normalized against $\beta$-actin serving as internal loading control. Relative levels of GRP78 and CHOP under each condition are plotted below the autoradiograms. C. Expression of GRP78 and CHOP mRNA in HLA-B27-expressing cells was detected by quantitative PCR. Data are presented as relative expression normalized by $18 \mathrm{~S}$ rRNA. Cells were incubated with or without IFN- $\gamma$; after 24-hour incubation, expression of GRP-78 and CHOP in HLA-B27-expressing U937 cells (U937-B27) was more intense than in the HLA-A2-expressing U937 cells (U937-A2) and U937 cells D. Total XBP-1 and the XBP-1 splice variant were analyzed by semiquantitative PCR. XBP-1 spliced $(\mathrm{S})$ is expressed as a percentage of total XBP-1 unspliced (U). Data are shown as means \pm SD of 3 independent experiments. *Significant differences $(\mathrm{p}<0.05)$ compared to control group. 
of XBP-1 splice variant to XBP-1 are shown in Figure 4D. We found that HLA-B27 modulated XBP-1 splicing following IFN- $\gamma$ stimulation.

Expression of UPR-associated proteins in HLA-B27-expres- sing PBMC of AS patients. PBMC of HLA-B27-positive AS patients were treated with IFN- $\gamma$ for $8 \mathrm{~h}$. HLA-B27 expression of HLA-B27-positive AS patients was increased significantly by incubation with IFN- $\gamma$ (Figure 5A). Western blots

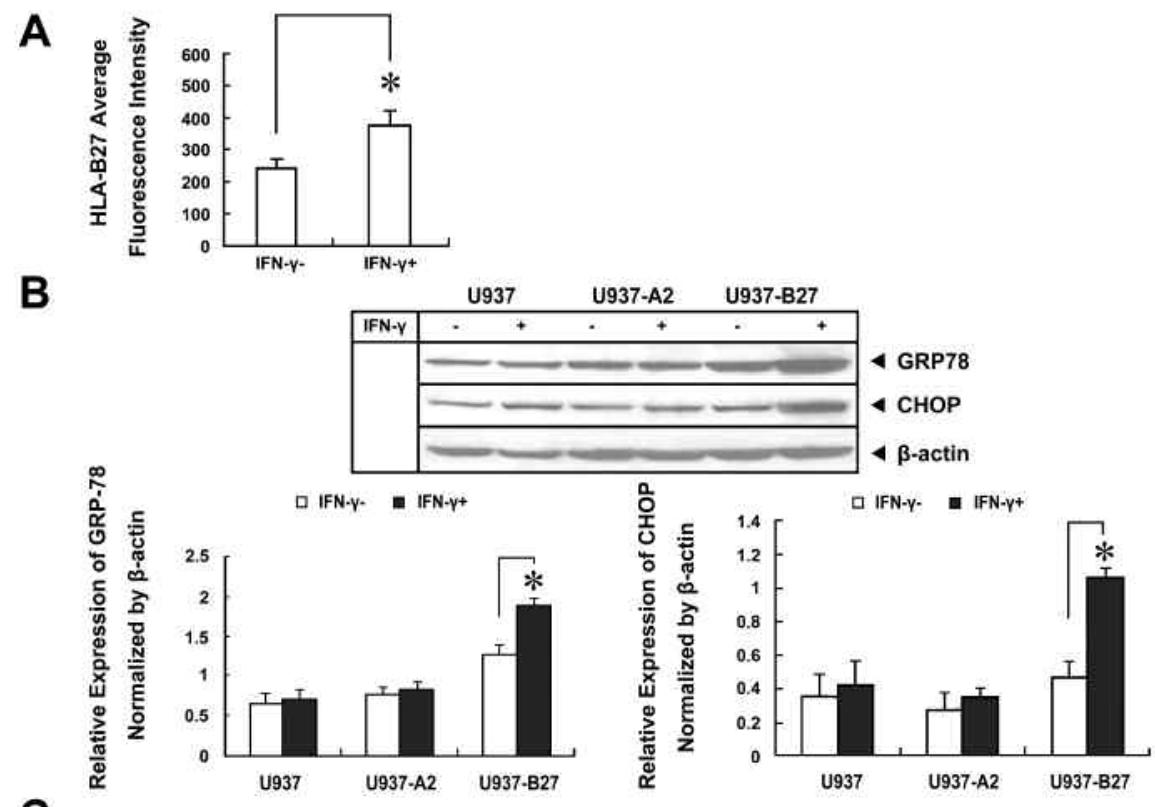

C
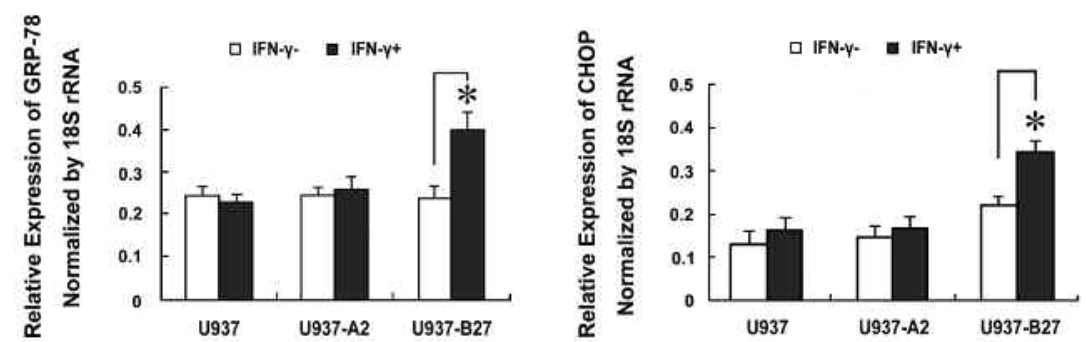

D

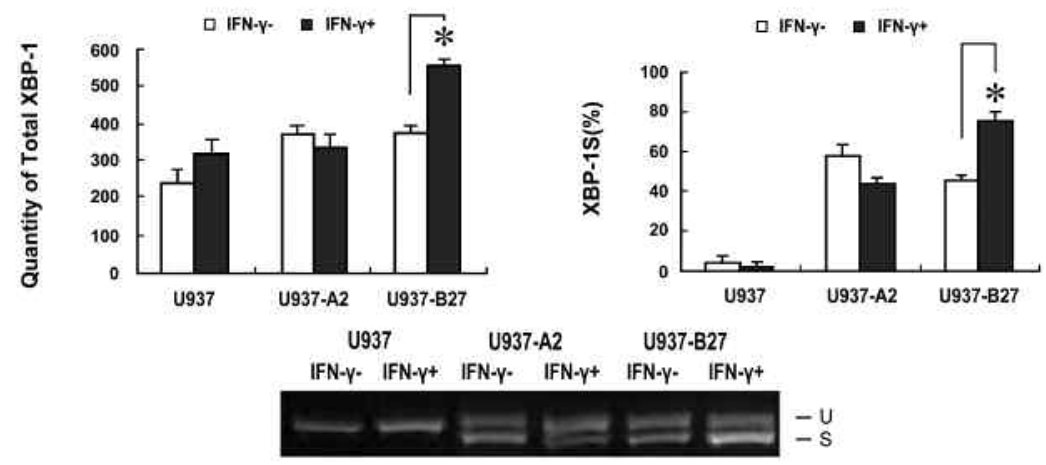

Figure 5. IFN- $\gamma$ can induce expression of UPR-associated proteins in PBMC of HLA-B27-positive AS patients. Healthy controls (N Control) and PBMC of 5 HLA-B27-negative AS patients (AS B27-), and 15 HLA-B27-positive AS patients (AS B27+) were incubated with $(\mathrm{IFN}-\gamma+)$ or without (IFN- $\gamma-$ ) interferon- $\gamma$ for 24 hours. A. HLA-B27 expression of HLA-B27-positive AS patients was detected by flow cytometry. B. GRP78 and CHOP protein extracts from cells were subjected to Western blot analysis with antibodies against GRP78, CHOP, and B-actin. The intensity of the protein bands was quantified by densitometry and normalized against $B$-actin serving as internal loading control. Relative levels of GRP78 under each condition are plotted below the autoradiograms. C. Expression of GRP78 and CHOP mRNA in PBMC was detected by quantitative PCR. Data are presented as relative expression normalized by $18 \mathrm{~S}$ rRNA. D. Total XBP-1 and the XBP-1 splice variant were analyzed using semiquantitative PCR. XBP-1 spliced (S) is expressed as a percentage of total XBP-1 unspliced (U). Data are shown as means \pm SD of 3 independent experiments. *Significant differences $(p<0.05)$ compared to control group. 
and quantitative real-time PCR also showed that GRP78 and CHOP expression in PBMC of HLA-B27-positive AS patients increased when treated with IFN- $\gamma(\mathrm{p}<0.05)$, but no significant differences were seen in HLA-B27-negative AS patients or controls (Figure 5B,5C). The results of XBP-1 mRNA showed a similar tendency (Figure 5D).

\section{DISCUSSION}

We found that the expression of UPR-related molecules, especially the expression of GRP78, was elevated in monocytes/macrophages of PB and SF in patients with SpA. These findings indicate that the UPR is possibly activated in monocytes/macrophages of patients with SpA, and UPR may participate in the pathogenesis of SpA. Based on these findings, we chose the human monocytic cell line U937 as host cell line in this study to investigate UPR activation in HLA-B27 whole-gene transfectants.

GRP78, also known as BiP, is a central regulator of ER homeostasis, owing to its multiple functional roles in protein folding, ER calcium binding, and controlling the activation of transmembrane ER stress sensors. ER stress induction of GRP78/BiP represents a major prosurvival arm of the $\mathrm{UPR}^{14,15,16}$. In addition to GRP78, many other molecules, such as XBP-1 (X-box binding protein 1) and CHOP (c/enhancer binding protein homologous protein 10 ), were reported to play important roles in UPR, and their levels were also taken as indicators of the degrees of UPR activation. Dickhout, et $a l^{17}$ have shown that UPR activation occurs during differentiation of monocytes into macrophages. The data indicated the presence of more "mature" or differentiating monocytes in $\mathrm{PB}$ of patients with SpA than in patients with OA or healthy controls ${ }^{17}$. Our findings of overexpression of UPR target genes in SpA are consistent with the report of $\mathrm{Gu}$, et $a l^{12}$, but provide further evidence for the existence of UPR activation in SpA monocytes/ macrophages.

Gu's studies and ours have suggested the existence of UPR in SpA, but which factors cause this UPR and affect it? T cell-involved cytokines (such as IL-2, TNF- $\alpha$, TNF- $\beta$, IFN- $\gamma$, IL-4, and IL-10) were found at higher levels in SF of patients with SpA compared with samples from patients with $\mathrm{OA}^{18,19,20}$. In our study, TNF- $\alpha$, IL-10, IL-6, and IL-1 were also found to be significantly higher in PBMC of AS patients than healthy controls. We presumed that the high levels of these cytokines may possibly increase expression of HLA-B27 in SpA monocytes/macrophages, thus inducing the UPR activation. In terms of the effect of cytokines on the promoter of the HLA-B27 gene, we found that only TNF- $\alpha$, IFN- $\alpha$, IFN- $\beta$, and IFN- $\gamma$ regulated HLA-B27 promoter activity in human monocytes, which corroborated the report from Zhao, et al that TNF- $\alpha$ and IFN, as the cytokines, activated HLA-B27 promoter $^{21}$. These findings together indicate that high levels of IFN- $\alpha$, IFN- $\beta$, and IFN- $\gamma$ lead to overexpression of HLA-B27 in monocytes/macrophages.
Penttinen, et $a l^{22}$ found that mRNA encoding BiP and CHOP were expressed at similar levels in stable U937 cell transfectants expressing HLA-A2, but they found no evidence for an ongoing UPR in HLA-B27 stably transfected U937 cell lines. Goodall, et $a l^{23}$ also reported that there were no significant differences in mRNA levels of BiP and XBP-1 between HLA-B27, A2-transfected U937 cells and control cells. Apart from our results that were similar to these studies, our Western blot and PCR results demonstrated that after incubation with HLA-B27 promoter-activating cytokine IFN- $\gamma$, expressions of GRP78, CHOP, and XBP-1 in HLA-B27 U937 cells were higher than those in A2-U937 cells, indicating that stimulation with IFN- $\gamma$ may induce the UPR in human monocytes. In PBMC of HLA-B27-positive patients with AS, we also found that IFN- $\gamma$ induced the increase of GRP78, CHOP, and XBP-1 expression, but no significant differences were seen in HLA-B27-negative patients with AS or healthy controls. These results suggest that upregulation of HLA-B27 is strongly correlated with the UPR activation when monocytes/macrophages are treated with IFN- $\gamma$.

Our findings of elevated expression of UPR-related molecules in monocytes/macrophages of patients with SpA indicate that the UPR may participate in the pathogenesis of SpA. TNF- $\alpha$ and IFN- $\alpha$, IFN- $\beta$, and IFN- $\gamma$ significantly activated HLA-B27 promoter in the U937 cell line, and expressions of GRP78 in HLA-B27-expressing U937 cells and PBMC of AS patients increased only by incubation with IFN- $\gamma$. These results suggest that stimulation with IFN- $\gamma$, the strongest HLA-B27 promoter-activating factor, might mediate UPR in human monocytes. TNF- $\alpha$ and IFN- $\alpha$, IFN- $\beta$, and IFN- $\gamma$ may play some very important roles in HLA-B27-associated pathogenesis. Further studies on the response of HLA-B27 gene to cytokines in different kinds of cells, especially primary human monocytes/macrophages, will deepen the understanding of the role of HLA-B27 in the pathogenesis of SpA.

\section{ACKNOWLEDGMENT}

We thank Prof. David Yu for his help and Like Zhao for providing the pmaxFP-Yellow-PRL/B27-pro vector and stable Hela HLA-B27 promoter transfectants.

\section{REFERENCES}

1. Arnett FC. Seronegative spondyloarthropathies. In: Dale DC, Federman DD, editors. ACP Medicine. New York: Web MD; 2004:1350.

2. Van der Linden SJ, van der Heijde D. Spondylarthopathies: ankylosing spondylitis. In: Ruddy S, Harris ED, Sledge CB, editors. Kelley's textbook of rheumatology. Philadelphia: WB Saunders; 2000:1039.

3. Smith JA, Marker-Hermann E, Colbert RA. Pathogenesis of ankylosing spondylitis: Current concepts. Best Pract Res Clin Rheumatol 2006;20:571-91.

4. Bowness P, Ridley A, Shaw J, Chan AT, Wong-Baeza I, Fleming M, et al. Th17 cells expressing KIR3DL2+ and responsive to HLA-B27 homodimers are increased in ankylosing spondylitis.

Personal non-commercial use only. The Journal of Rheumatology Copyright $@$ $\subset$ 2012. All rights reserved. 
J Immunol 2011; 150:2672-80.

5. Taurog JD, Maika SD, Simmons WA, Breban M, Hammer RE. Susceptibility to inflammatory disease in HLA-B27 transgenic rat lines correlates with the level of B27 expression. J Immunol 1993;150:4168-78.

6. Cauli A, Dessole G, Fiorillo MT, Vacca A, Mameli A, Bitti P, et al. Increased level of HLA-B27 expression in ankylosing spondylitis patients compared with healthy HLA-B27-positive subjects: A possible further susceptibility factor for the development of disease. Rheumatology 2002;41:1375-9.

7. Mear JP, Schreiber KL, Münz C, Zhu X, Stevanovic S, Rammensee HG, et al. Misfolding of HLA-B27 as a result of its B pocket suggests a novel mechanism for its role in susceptibility to spondyloarthropathies. J Immunol 1999;163:6665-70.

8. Allen RL, O'Callaghan CA, McMichael AJ, Bowness P. HLA-B27 can form a novel beta2-microglobulin-free heavy chain homodimer structure. J Immunol 1999;162:5045-8.

9. Colbert RA. HLA-B27 misfolding: A solution to the spondyloarthropathy conundrum? Mol Med Today 2000;6:224-30.

10. Turner MJ, Sowders DP, DeLay ML, Mohapatra R, Bai S, Smith JA, et al. HLA-B27 misfolding in transgenic rats is associated with activation of the unfolded protein response. J Immunol 2005; 175:2438-48

11. Turner MJ, DeLay ML, Bai S, Klenk E, Colbert RA. HLA-B27 up-regulation causes accumulation of misfolded heavy chains and correlates with the magnitude of the unfolded protein response in transgenic rats: Implications for the pathogenesis of spondylarthritis-like disease. Arthritis Rheum 2007;56:215-23.

12. Gu J, Rihl M, Marker-Hermann E, Baeten D, Kuipers JG, Song YW, et al. Clues to pathogenesis of spondyloarthropathy derived from synovial fluid mononuclear cell gene expression profiles. J Rheumatol 2002;29:2159-64.

13. Yoshida H, Matsui T, Yamamoto A, Okada T, Mori K. XBP1 mRNA is induced by ATF6 and spliced by IRE1 in response to ER stress to produce a highly active transcription factor. Cell 2001;107:881-91.
14. Kaufman RJ. Orchestrating the unfolded protein response in health and disease. J Clin Invest 2002;110:1389-98.

15. Reddy RK, Mao C, Baumeister P, Austin RC, Kaufman RJ, Lee AS. Endoplasmic reticulum chaperone protein GRP78 protects cells from apoptosis induced by topoisomerase inhibitors: Role of ATP binding site in suppression of caspase-7 activation. J Biol Chem 2003;278:20915-24.

16. Lee AS. The glucose-regulated proteins: Stress induction and clinical applications. Trends Biochem Sci 2001;26:504-10.

17. Dickhout JG, Lhoták Š, Hilditch BA, Basseri S, Colgan SM, Lynn $\mathrm{EG}$, et al. Induction of the unfolded protein response after monocyte to macrophage differentiation augments cell survival in early atherosclerotic lesions. FASEB J 2011;25:576-89.

18. Partsch G, Wagner E, Leeb BF, Broll H, Dunky A, Smolen JS. T cell derived cytokines in psoriatic arthritis synovial fluids. Ann Rheum Dis 1998;57:691-3.

19. Schlaak JF, Pfers I, Meyer zum Büschenfelde K-H, Marker-Hermann E. Different cytokine profiles in the synovial fluid of patients with osteoarthritis, rheumatoid arthritis and seronegative spondylarthropathies. Clin Exp Rheumatol 1996;14:155-62.

20. Cañete JD, Martínez SE, Farrés J, Sanmarti R, Blay M, Gomez A, et al. Differential Th1/Th2 cytokine patterns in chronic arthritis: Interferon gamma is highly expressed in synovium of rheumatoid arthritis compared with seronegative spondyloarthropathies. Ann Rheum Dis 2000;59:263-8.

21. Zhao L, Fong Y, Granfors K, Gu J, Yu D. Identification of cytokines that might enhance the promoter activity of HLA-B27. J Rheumatol 2008;35:862-8.

22. Penttinen MA, Heiskanen KM, Mohapatra R, DeLay ML, Colbert RA, Sistonen L, et al. Enhanced intracellular replication of Salmonella in HLA-B27 expressing human monocytic cells: Dependency on glutamic acid at position 45 in the B pocket of HLA-B27. Arthritis Rheum 2004;50:2255-63.

23. Goodall JC, Ellis L, Yeo GS, Gaston JS. Does HLA-B27 influence the monocyte inflammatory response to lipopolysaccharide? Rheumatology 2007;46:232-7. 


\section{Correction}

Interferon- $\gamma$ Contributes to HLA-B27-associated Unfolded Protein Response in Spondyloarthropathies

Feng Y, Ding J, Fan CM, Zhu P. Interferon- $\gamma$ contributes to HLA-B27-associated unfolded protein response in spondyloarthropathies. J Rheumatol 2012;39:574-82. The labels describing graphs of Figure 5 were incorrect; the figure with correct labeling is given below. We regret the error.

doi:10.3899/jrheum.101257.C1

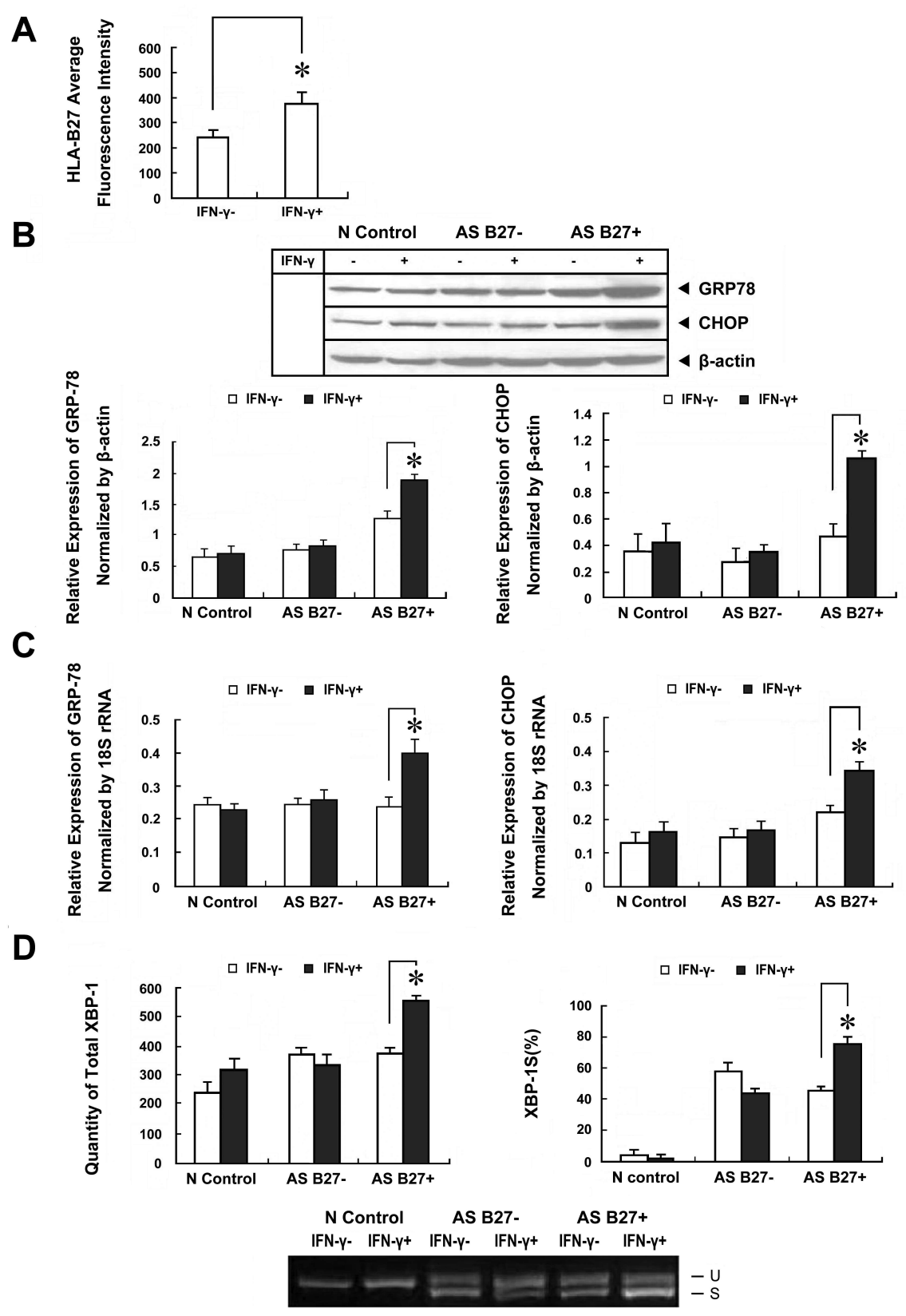

Figure 5. IFN- $\gamma$ can induce expression of UPR-associated proteins in PBMC of HLA-B27-positive AS patients. Healthy controls (N Control) and PBMC of 5 HLA-B27-negative AS patients (AS B27-), and 15 HLA-B27-positive AS patients (AS B27+) were incubated with (IFN- $\gamma+$ ) or without (IFN- $\gamma-$ ) interferon- $\gamma$ for 24 hours. A. HLA-B27 expression of HLA-B27-positive AS patients was detected by flow cytometry. B. GRP78 and CHOP protein extracts from cells were subjected to Western blot analysis with antibodies against GRP78, CHOP, and B-actin. The intensity of the protein bands was quantified by densitometry and normalized against $\beta$-actin serving as internal loading control. Relative levels of GRP78 under each condition are plotted below the autoradiograms. C. Expression of GRP78 and CHOP mRNA in PBMC was detected by quantitative PCR. Data are presented as relative expression normalized by $18 \mathrm{~S}$ rRNA. D. Total XBP-1 and the XBP-1 splice variant were analyzed using semiquantitative PCR. XBP-1 spliced (S) is expressed as a percentage of total XBP-1 unspliced (U). Data are shown as means \pm SD of 3 independent experiments. *Significant differences $(\mathrm{p}<0.05)$ compared to control group. 